\title{
KONSEP PENDIDIKAN ISLAM PERSPEKTIF MAHMUD YUNUS DAN IMPLIKASINYA TERHADAP PEMBELAJARAN PAI DI SEKOLAH
}

\author{
Ashfira Nurza,* Munawar Rahmat, dan Fahrudin \\ Universitas Pendidikan Indonesia, Bandung \\ *E-mail:ashfi.nurza1107@gmail.com
}

\begin{abstract}
This research aims to find the concept of education according to Mahmud Yunus and its implication to Islamic Religious Education at school. This research is library research by using qualitativedescriptive approach. Based on this research, it is known that Islamic Education goal according to Mahmud Yunus is to form noble character (akblak mabmudab) of the students and they are experts in both general and religious sciences. Materials of Islamic Education in Mabmud Yunus' view in geleral can be divided ito three: math, skill, and drawing. In specific, Mahmud Yunus divides materials of Islamic Education based on levels of education.Methods of Islamic Education to him are story telling, question-answer, discussion, modelling, accustoming, and speech. The last, evaluation of Islamic Education used are school examination, general examination, and modern examination. The concept of education according to Mahmud Yunus, in the researchers' view has implication to the process of Islamic Religious Education insctruction at school, either in the goal, materials, method, or in the evaluation.
\end{abstract}

Keywords: Islamic Education, Implication, Islamic Religious Education Instruction

\begin{abstract}
ABSTRAK
Penelitian ini bertujuan untuk menemukan konsep pendidikan Islam perspektif Mahmud Yunus dan implikasinya terhadap pembelajaran PAI di sekolah.Penelitian ini menggunakan metode penelitian deskriptif melalui pendekatan kualitatif dengan menggunakan teknik studi literatur. Berdasarkan basil penelitian diketabui bahwa tujuan pendidikan Islam perspektif Mabmud Yunus adalah membentuk akblak mulia peserta didik dan peserta didik dapat dibandalkan dalam ilmu umum dan ilmu agama.Materi pendidikan Islam perspektif Mahmud Yunus secara umum dibagi menjadi tiga yaitu matematika, keterampilan, dan melukis. Secara kbusus Mahmud Yunus membagi materi Pendidikan Islam berdasarkan tingkat pendidikan.Metode pendidikan Islam yaitu metode kisah, metode tanya jawab, metode diskusi, metode teladan, metode pembiasaan dan metode ceramah. Evaluasi pendidikan Islam yang digunakan yaitu berupa ujian sekolah, ujian umum, dan ujian modern. Konsep pendidikan Islam perspektif Mahmud Yunus ini memiliki implikasi terhadap proses pembelajaran PAI di sekolah, baik pada tujuan pembelajaran, materi pembelajaran, metode pembelajaran, dan evaluasi pembelajaran.
\end{abstract}

Kata kunci: Pendidikan Islam, Implikasi, Pembelajaran Pendidikan Agama Islam 


\section{PENDAHULUAN}

Dalam masyarakat yang dinamis, pendidikan memegang peranan penting yang dapat menentukan eksistensi dan perkembangan masyarakat, baik dari segi sosial, politik, ekonomi, dan kebudayaan. Pendidikan merupakan usaha melestarikan dan menstransformasikan nilainilai sosiokultural dalam segala aspek dan jenisnya kepada generasi penerus. Pendidikan merupakan kunci dari segala bentuk kemajuan dan kesejahteraan hidup umat manusia sepanjang sejarah (Asnawan, 2011, hlm. 17-18). Pendidikan pada hakikatnya adalah suatu ikhtiar untuk mengubah manusia ke arah yang lebih baik, dan inti dari perubahan diri manusia yang dimaksud adalah perubahan nilai (Fakhruddin, 2014)

Untuk meralisasikan tugas kedudukan manusia dapat ditempuh manusia lewat pendidikan. Namun tidak semua pendidikan dapat mengemban tugas dan fungsi manusia. Dan nampaknya satu-satunya konsep pendidikan yang dapat dikembangkan adalah konsep pendidikan Islam (Ramayulis, 2008, hlm. 12).

Para tokoh pendidikan Islam bertahun-tahun yang lalu sudah memikirkan dan menemukan konsep pendidikan Islam yang tepat untuk membentuk pribadi muslim yang sesuai dengan tujuan pendidikan Islam. Namun, hingga saat ini pelaksanaan pendidikan Islam masih belum sesuai konsep pendidikan Islam yang telah ada dan tujuan pendidikan Islam belum tercapai sepenuhnya. Pada perkembangannya, saat ini di dunia pendidikan masih dirasakan adanya pemisahan antara ilmu umum dan ilmu agama. Dapat dilihat dalam pembagian jam pelajaran, untuk pelajaran umum jam pelajarannya bisa hampir dua kali lipat dari pelajaran PAI (pendidikan agama Islam). Untuk kurikulum KTSP (kurikulum tingkat satuan pendidikan) pelajaran PAI dua jam pelajaran dan tiga jam pelajaran untuk kurikulum KURTILAS (kurikulum dua ribu tiga belas).

Akibat kurangnya jam pelajaran PAI tersebut, di lapangan masih banyak peserta didik yang berprilaku di luar aturan agama. Yang paling mencolok saat ini adalah bebasnya para generasi muslim memperlihatkan pergaulan antara laki-laki dan perempuan yang melewati batas.

Pembelajaran PAI sangatlah penting bagi pembentukan karakter dan akhlak peserta didik. Pembelajaran PAI bukanlah mata pelajaran pelengkap mata pelajaran lainnya, namun lebih daripada itu, dengan pembelajaran PAI di sekolah, diharapkan peserta didik menjadi peserta didik yang berkepribadian yang jujur, bertanggung jawab, dan berakhlak mulia. Apalagi di saat akhlak bangsa yang sedang hancur dan terpuruk seperti sekarang ini (Budi, Rahmat, \& Kosasih, 2015, hlm. 193).

Menurut Fahrudin (2014, hlm. 41$42)$, orang tua memegang peranan yang sangat penting dalam mendidik anakanaknya. Baik buruknya anak-anak di masa yang akan datang banyak ditentukan oleh pendidikan dan bimbingan orang tuanya. Karena di dalam keluarga itulah anak-anak pertama kali memperoleh pendidikan sebelum pendidikan-pendidikan yang lain.

Untuk menyempurnakan pendidikan Islam di lembaga-lembaga seperti sekolah ataupun universitas adalah 
melaksanakan kurikulum integrated secara tepat. Tidak hanya memasukan pelajaran PAI tetapi pada setiap mata pelajaran harus diintegrasikan dengan ilmu agama Islam karena semua ilmu umum awal mulanya ditemukan oleh penemupenemu Islam. Sehingga peserta didik akan mempelajari Islam tidak hanya pada mata pelajaran PAI tetapi disemua pelajaran. Dan penekanannya disini adalah setaip pendidik muslim adalah tidak hanya paham ilmu umumnya saja tapi juga paham ilmu agama sehingga saat penyampaian materi ilmu umum bisa diintegrasikan dengan ilmu agama.

Mengenai permasalahan pendidikan Islam di atas, salah satu tokoh pendidikan Islam Mahmud Yunus sudah memikirkannya dan menemukan konsep pendidikan Islam yang tepat agar tujuan pendidikan Islam tercapai. Kurikulum integrated yang pertama kali mencetuskan adalah Mahmud Yunus. Mahmud Yunus juga yang mempelopori mata pelajaran PAI dimasukkan ke dalam kurikulum di sekolah-sekolah umum.

\section{METODE PENELITIAN}

Penelitian ini menggunakan pendekatan kualitatif. Pendekatan kualitatif adalah penelitian yang bertujuan untuk mendapatkan pemahaman yang mendalam tentang masalah-masalah manusia dan sosial, bukan mendeskripsikan bagian permukaan dari suatu realitas sebagaimana dilakukan penelitian kuantitatif dengan positivismenya. Peneliti menginterprestasikan bagaimana subjek memperoleh makna dari lingkungan sekeliling, dan bagaimana makna tersebut mempengaruhi perilaku mereka. Penelitian dilakukan dalam latar yang alamiah bukan hasil perlakuan atau manipulasi variabel yang dilibatkan (Gunawan, 2014, hlm. 85).

Penelitian ini menggunakan metode kajian pustaka (library research) dengan mengumpulkan data-data yang berkaitan dengan pemikiran Mahmud Yunus. Menurut Zed (2008, hlm. 3) riset pustaka tidak hanya sekedar urusan membaca dan mencatat literatur atau buku-buku sebagaimana yang sering dipahami banyak orang selama ini. Meode kajian pusataka (library research) ialah serangkaian kegiatan yang berkenaan dengan metode pengumpulan data pustaka, membaca dan mencatat serta mengolah bahan penelitian.

\section{HASIL PENELITIAN DAN PEMBAHASAN}

\section{Biografi Mahmud Yunus}

Ia dilahirkan dari pasangan Yunus B. Incek dan Hafsah binti Imam Sami'un. Mahmud Yunus lahir 10 Februari 1899 di Desa Sungayang, Batusangkar, Sumatera Barat kelak menajadi pendidik dan ahli tafsir Alquran.Ayahnya seorang imam, sedangkan ibunya adalah anak dari Engku Gadang M. Thahir bin Ali seorang alim dan pendiri sebuah surau (semacam pesantren di Jawa) (Herry Muhammad, 2006, hlm. 85).

Mahmud Yunus wafat pada tanggal 16 Januari 1982.Ia termasuk tokoh pendidikan Islam Indonesia yang gigih memperjuangkan masuknya pendidikan agama ke sekolah umum dan ikut berusaha memperjuangkan berdirinya 
Perguruan Tinggi Agama Islam Negeri (PTAIN). Sejak kecil Mahmud Yunus sudah memperlihatkan minat dan kecendrungannya yang kuat untuk memperdalam ilmu agama Islam. Ketika berumur 7 tahun ia belajar membaca Alquran di bawah bimbingan kakeknya Engku Gadang (Nata, 2005, hlm. 57).

Adapun pendidikan umumnya diperolehnya dari Sekolah Rakyat. Hanya sampai tahun keempat, ia sudah mulai bosan. Pasalnya, pelajaran yang diperolehnya sering diulang-ulang oleh sang guru. Mahmud pun keluar. Pada saat bersamaan, H.M. Thaib Umar mendirikan Madrasah School di surau Tanjung Pauh, tahun 1910. Maka, Mahmud pun dimasukkan oleh ayahnya ke Madrasah School tersebut. Di sini, ia belajar nahwu, sharaf, bahasa Arab, dan matematika. Pagi sekolah, sore dan malam hari ia mengajar Alquran di Surau yang di asuh kakeknya. Kecemerlangan Mahmud dalam menerima pelajaran, diakui oleh para ustadz yang mengajarnya. Maka, sambil belajar, di usianya yang baru 16 tahun (1917), Mahmud sudah mampu mengajar beberapa kitab, antara lain al-Mahally, alFiyah ibn Aqil dan Jam'al al-jawami (Herry Muhammad, 2006, hlm. 86).

Di sela-sela kesibukannya sebagai guru Mahmud Yunus menghadiri rapatrapat besar alim ulama seluruh Minangkabau tahun 1919 (mewakili Syekh H.M Thaib pendiri madrasah). Dalam musyawarah tersebut diputuskan untuk mendirikan PGAI (Persatuan Guru Agama Islam) Mahmud Yunus termasuk salah satu anggotanya. Mahmud Yunus juga ikut memprakarsai berdirinya perkumpulan pelajar-pelajar Islam Batusangkar dengan nama "Sumatera Tha- walib" tahun 1920 (Zulmardi, 2009, hlm. 14).

Selanjutnya pada bulan maret 1923, Mahmud Yunus menunaikan ibadah haji lewat Penang, Malaysia. Setelah menunaikan ibadah haji ini, ia belajar di Mesir untuk melanjutkan studinya yang selama ini menjadi cita-citanya. Pada tahun1924 Mahmud Yunus mendapat kesempatan untuk melanjutkan pendidikan ke Mesir Universitas AlAzhar. Setahun kemudian ia memperoleh Shabadah Aliyah. Kemudian ia melanjutkan studinya ke Madrasah Darul UlumAl-Ulya Cairo dan tercatat sebagai mahasiswa pertama dari Indonesia. Tahun 1930 setelah mengambil spesialisasi Tadris, akhirnya Mahmud Yunus berhasil memperoleh ijazah Tadris dari perguruan tersebut (Zulmardi, 2009, hlm. 14).

Dengan dua ijazah yang dimilikinya bakatnya sebagai seorang guru betul-betul teraplikasi. Hal ini terbukti dengan kemampuannya memimpin sekolah-sekolah di samping mengajar, seperti Sekolah Al-Jami'ah Al-Islamiyah Batusangkar (1931-1932). Kuliah Muallimin Normal Islam Padang Tahun 19321946. Akademi Pamong Praja di Bukittinggi tahun 1948-1949. Akademi Dinas Ilmu Agama (ADIA) Jakarta tahun 1957-1980, menjadi Dekan dan Guru Besar pada Fakultas Tarbiyah IAIN Syarif Hidayatullah Jakarta tahun 19601963. Rektor IAIN Imam Bonjol Padang tahun1966-1971. Atas jasa-jasanya di bidang pendidikan ini IAIN Syarif Hidayatullah Jakarta menganugrahkan Mahmud Yunus Doktor Honoris Causa dalam ilmu Tarbiyah (Zulmardi, 2009, hlm. 14). 
Menurut Zulmardi dalam (2009, hlm. 15-16) Mahmud Yunus adalah penulis yang cukup produktif. Banyak bukunya telah diterbitkan dan tersebar di tanah air. Buku-buku tersebut meliputi berbagai bidang ilmu, di antaranya bidang pendidikan, hukum Islam (fikih), tafsir, akhlak, ilmu jiwa, sejara Islam dan lain-lain.

\section{Asas-asas Perencanaan Pengajran \\ Pendidikan Islam Mahmud Yunus}

Menurut Yunus (1990, hlm. 36) untuk membuat rencana pengajaran dan memilih mata pelajaran haruslah diperhatikan asas-asas di bawah ini, yaitu:

a. Memikirkan tujuan-tujuan yang diinginkan oleh pendidikan.

b. Memikirkan keinginan dan kecendrungan hati peserta didik.

c. Memperhatikan kesehatan peserta didik.

d. Memilih kegiatan pembelajaran dengan bijaksana dan menyusun langkah-langkah yang dapat menumbuhkan keaktifan peserta didik.

e. Memikirkan tingkat kecerdasan peserta didik.

f. Memperhatikan faktor-faktor keadaan tempat dan alam sekitar peserta didik.

g. Memikirkan keadaan lingkungan masyarakat peserta didik, akhlak dan adat istiadat.

h. Memikirkan untuk mempersiapkan peserta didik untuk kehidupan selanjutnya. Oleh karena itu haru dipilih materi-materi yang berhubungan dengan kehidupan.

\section{Tujuan Pendidikan Islam Mahmud Yunus}

Tujuan pendidikan Islam menurut Yunus ialah menyiapkan anak-anak, agar di waktu dewasa kelak mereka cakap melakukan pekerjaan dunia dan amalan akhirat, sehingga tercipta kebahagiaan dunia dan akhirat. Agar anak-anak cakap melaksanakan amalan akhirat mereka harus dididik, agar beriman teguh dan beramal saleh. Untuk pendidikan itu harus dijarkan keimanan, akhlak, ibadah da isi-isi Alquran yang berhubungan dengan hal-hal yang wajib dikerjakan dan hal-hal yang haram dikerjakan. Selanjutnya agar anak-anak cakap melaksanakan pekerjaan dunia, mereka harus dididik untuk mengerjakan salah satu dari macam-macam bidang, seperti bertani, berdagang, beternak, bertukang, menjadi guru, pegawai negeri, buruh dan sebagainya sesuai dengan bakat dan minat masing-masing anak-anak (Yunus, 1990, hlm. 10).

Menurut Yunus (1990, hlm. 12) tujuan utama pendidikan Islam yang harus dilaksanakan umat Islam oleh ulama, guru-guru agama dan pemimpinpemimpin Islam yaitu pendidikan akhlak. Tugas pertama yang harus dilaksanakan oleh ulama, guru-guru agama dan pemimpin-pemimpin Islam ialah mendidik anak-anak, pemuda-pemuda, putra-putri, orang dewasa dan masyarakat semua untuk berakhlak mulia dan berbudi pekerti yang halus.

\section{Materi Pendidikan Islam Mahmud Yunus}

Menurut Yunus (1990, hlm. 113), macam-macam materi pendidikan Islam atau mata pelajaran dibagi menjadi tiga, yaitu: 
a. Mata pelajaran untuk mendapatkan ilmu pengetahuan. Mata pelajaran ini membutuhkan pikiran, pembahasan dan diskusi agar peserta didik dapat memahaminya seperti pelajaran ilmu pengetahuan alam, kimia, matematika, nahu/saraf, ilmu bumi (geografi), sejarah dan sebagainya.

b. Mata pelajaran untuk mencapai ketangkasan dan kemahiran.Ialah pelajaran-pelajaran kesenian yang praktis yang membutuhkan contoh dan latihan agar mahir dan tangkas mengerjakannya. Contohnya pelajaran menulis, menggambar, keterampilan tangan, seni suara dan sebagainya.

c. Mata pelajaran untuk memperhalus perasaan.Tujuannya ialah mendidik peserta didik agar mencintai keindahan dan menghargainya serta takjub atas keindahan tersebut. Dalam pelajaran seni suara, lagu-lagu dan sebagainya, hal yang paling penting adalah pendidikan rasa dan perasaan dengan pendiidkan keindahan. Selain dari seni suara yang dipelajari adalah, pantun, syair,dan melukis keindahan alam ciptaan Allah.

Lebih khususnya dalam pemaparan materi pendidikan Islam, disesuaikan berdasarkan tingkat satuan pendidikan peserta didik. Tingkatan pelaksanaan pendidikan Islam dibagi menjadi empat tingkatan yaitu pendidikan Islam di sekolah dasar (SD), sekolah menengah pertama (SMP), sekolah menengah akhir (SMA) dan yang terakhir perguruan tinggi. Mahmud Yunus membagi materi pendidikan Islam sebagai berikut, yaitu:
a. Materi keimanan.
b. Materi akhlak.
c. Materi ibadah.
d. Materi Alquran.
e. Sejarah Islam.
f. Islam dan Kemasyarakatan.
g. Konsepsi Islam
h. Ihsan.

\section{Metode Pendidikan Islam Mahmud Yunus}

Dalam hal metode pendidikan Islam Mahmud Yunus menyesuaikan metode tersebut berdasarkan mata pelajaran atau materi dan tingkat pendidikan, yaitu:

a. Materi keimanan.

Metode mengajarkan keimanan di tingkat SD dibagi menjadi dua cara yaitu metode menggunakan kisah dan tidak menggunakan kisah. Metode yang menggunakan kisah adalah guru menggunakan kisah nabi-nabi dan orangorang mukmin untuk menyampaikan materi keimanan. Metode kedua adalah tidak menggunakan kisah, metode yang digunakan adalah tanya jawab mengenai dalil yang memperkuat keimanan peserta didik dan menggunakan metode amtsal atau permisalah-permisalan.

Metode mengajarkan keimanan di tingkat SMP dan SMA menggunakan metode tanya jawab tentang akidah dengan memberikan contoh-contoh. Metode mengajarkan keimanan di tingkat perguruan tinggi dengan menggunakaan metode diskusi.Karena pada tingtat perguruan tinggi, metode perkuliahannya lebih menekankan peserta didik yang menelaah sendiri jadi untuk memahami materi keimanan peserta diajak berdiskusi menegenai akidah, pendapat para ulama dan para ahli filsafat.

b. Materi akhlak. 
Metode yang digunakan dalam penyampaian materi di SD akhlak terbagi menjadi 2 yaitu:

1. Metode kisah. Penyampaian materi akhlak dengan menggunakan kisahkisah pada masa nabi ataupun para orang mukmin yang berhubungan dengan akhlak.

2. Metode diskusi atau tanya jawab. Guru melakukan tanya jawab tentang akhlak.

\section{c. Materi ibadah.}

Metode yang digunakan dalam penyampaian materi ibadah di tingkat SD adalah metode teladan. Metode teladan digunakan adalah metode teladan yang disengaja sebagaimana Tafsir (2011, hlm. 143) ) keteladanan yang disengaja ialah keteladanan yang memang disertai penjelasan atau perintah agar meneladani. Jadi guru memberikan penjelasan mengenai tata cara sholat dan meminta peserta didik untuk memperhatikan agar nanti bisa mempratikkannya, karena materi ibadah pada tingkat SD itu mengajarkan tata cara ibadah, contohnya salat. Pada tingkat SMP metode yang dgunakan adalah tanya jawab mengenai ibadah.

Materi ibadah di tingkat SMA lebih mendalam, maka disebut materi fikih. Ketika mempelajari salat maka metode pembelajarannya adalah tanya jawab atau diskusi mengenai rukun salat. Di tingkat perguruan tinggi metodenya adalah praktik ibadah dengan baik dan benar. Kemudian dalam penyampaian materi hikmah ibadah, filsafat dari ibadah menggunakan metode diskusi.

d. Materi Alquran.
Metode yang digunakan pada materi Alquran ditingkat SD menggunakan metode teladan dan pembiasaan karena isi materinya adalah menghafal suratsurat di dalam Alquran.Pada materi ini guru mencontohkan dengan membaca ayat Alquran kemudian diulang oleh peserta didik. Metode pembiasaan ini ialah pengulangan contohnya guru mengulang-ulang membaca satu ayat kemudian peserta didik mengulang. Sebagaimana yang dikatakan Tafsir (2011, hlm. 145) pembiasaan berintikan pengulangan, maka metode pembiasaan juga berguna untuk menguatkan hafalan. Rasulullah berulang-ulang berdoa dengan doa yang sama. Akibatnya, beliau hafal doa itu, dan sahabatnya yang mendengarkan doa yang berulang-ulang juga hafal doa itu.

e. Sejarah Islam.

Metode yang digunakan dalam penyampaian materi sejarah Islam adalah metode kisah.

f. Islam dan Kemasyarakatan.

Metode yang digunakan padamateri Islam dan kemasyarakatanadalah metode ceramah dan tanya jawab.

g. Ihsan.

Metode yang dilakukan adalah diskusi mengenai tujuan melaksanakan ibadah dan hikmahnya melaksanakan ibadah.

\section{Evaluasi Pendidikan Islam Mah- mud Yunus}

Menurut Yunus (1990, hlm. 141142) evaluasi dibagi menjadi empat dan evalusi tersebut disebut ujian, yaitu :

1) Ujian sekolah. 
Ujian sekolah ialah ujian yang dilakukan oleh sekolah untuk mengetahui pemahaman peserta didik tentang pelajaran yang telah dipelajari.Contohnya ulangan harian.

2) Ujian umum.

Ujian umum ialah ujian yang dilakukan oleh suatu badan instansi pemerintah.. Contohnya adalah ujian nasional (UN).

3) Ujian biasa

Ujian biasa ialah ujian yang biasa dilakukan di Indonesia selama ini, yaitu ujian yang membutuhkan jawaban yang panjang, karangan yang baik dan pikiran yang teratur.

4) Ujian modern

Ujian modern ialah ujian yang membutuhkan jawaban satu kata, tanda atau testing.

\section{Implikasi Konsep Pendidikan Islam Mahmud Yunus Terhadap Pembelajaran PAI dI Sekolah}

Konsep pendidikan Islam Mahmud Yunus memiliki implikasi terhadap pembelajaran PAI di sekolah, yaitu:

1) Implikasi terhadap tujuan pembelajaran

Tujuan pendidikan Islam ialah menyiapkan anak-anak, agar di waktu dewasa kelak mereka cakap melakukan pekerjaan dunia dan amalan akhirat, sehingga tercipta kebahagiaan dunia dan akhirat. Agar anak-anak cakap melaksanakan amalan akhirat mereka harus dididik, agar beriman teguh dan beramal saleh (Yunus, 1990, hlm. 10). Selanjutnya menurut Yunus (1990, hlm. 12) tujuan utama pendidikan Islam yang harus dilaksanakan umat Islam oleh ulama, guru-guru agama dan pemimpin- pemimpin Islam yaitu pendidikan akhlak.Tugas pertama yang harus dilaksanakan oleh ulama, guru-guru agama dan pemimpin-pemimpin Islam ialah mendidik anak-anak, pemudapemuda, putra-putri, orang dewasa dan masyarakat semua untuk berakhlak mulia dan berbudi pekerti yang halus.

Pembelajaran PAI saat ini tidak hanya pemahaman peserta didik terhadap materi, karena dalam penilaian, akhlak peserta didik termasuk ke dalam penilaian. Jika peserta didik paham terhadap ilmu tetapi tidak memiliki akhlak mulia maka akan mengahsilkan koruptor seperti saat ini. Maka tujuan pembelajaran PAI hendaknya mengarahkan peserta didik memiliki keimanan dan berakhlak mulia. Mahmud Yunus menjelaskan bahwa tujuan pendidikan Islam adalah setelah menjalani pendidikan Islam dalam bentuk proses pembelajaran PAI peserta didik cakap dalam melaksanakan pekerjaan duniawi dan akhirat. Selanjutnya tujuan pendidikan Islam Mahmud Yunus yang utama adalah membentuk akhlak peserta didik. Apabila telah terbentuk akhlak mulia peserta didik, maka peserta didik akan mencapai kebahagiaan dunia dan akhirat. Implikasinya terhadap pembelajaran PAI adalah bahwa pendidikan Islam harus menghasilkan peserta didik yang tidak hanya handal dalam ilmu umum atau hal-hal yang duniawi tetapi juga handal dalam ilmu dan amalan yang akan dibawa hingga akhirat nanti. Dan untuk mencapai hal tersebut maka peserta didik harus mencapai tujuan utama pendidikan Islam yaitu berakhlak mulia.

2) Implikasi terhadap materi pembelajaran 
Materi pembelajaran adalah salah satu komponen yang penting dalam pembelajaran PAI. Mahmud Yunus telah membahas mengenai materi pendidikan Islam yang akan digunakan dalam pembelajaran PAI.

Pendidikan agama Islam menjadi landasan untuk pembelajaran ilmu pengetahuan lainnya. Menurut Mahmud Yunus materi yang diajarkan dalam pedidikan Islam yang diaplikasikan pada pembelajaran PAI adalah keimanan, akhlak, ibadah, Alquran, sejarah Islam, Islam dan kemasyarakatan, dan Ihsan. Implikasinya terhadap pembelajaran PAI, yaitu pada materi keimanan.Materi keimanan salah satu materi yang penting. Dengan materi keimanan proses pembelajaran lainnya tidak hanya bersifat duniawi tetapi berlandaskan keimanan yang dimiliki peserta didik. Materi keimanan juga menjadi dasar untuk peserta didik mempelajari materi selanjutnya.

Materi akhlak adalah untuk pembuktian keimanan peserta didik. Peserta didik yang sudah mempelajari keimanan dan sudah beriman maka haru dikorelasikan dengan berkahlak mulia terhadap Allah dan sesama manusi. Kemudian materi Ibadah adalah kewajiban seorang yang beriman dan berakhlak mulia. Peserta didik yang sudah beriman dan memiliki akhlak mulia akan melaksanakan ibadah yang diwajibkan dan disunahkan.

Materi Alquran dan hadis dipelajari pada pembelajaran PAI adalah untuk memahami makna Alquran dan hadis. Alquran dan hadis merupakan pegangan hidup seorang muslim. Dengan mempelajari Alquran dan hadis peserta didik akan memahaminya dan mengaplikasikannya dalam kehidupan sehari-hari. Materi sejarah Islam adalah untuk mengetahui awal mula datangnya Islam, sehingga setelah peserta didik mengetahui sejarah Islam tersebut semakin kuat keimanan peserta didik. Dan yang terakhir materi Islam dan kemasyarakatan adalah wujud dari berkahlak mulia yaitu hubungan dengan sesama manusia.

3) Implikasi terhadap metode pembelajaran

Pada metode pendidikan Islam Mahmud Yunus, juga dipratikkan pada pembelajaran PAI terdapat beberapa metode yang diaplikasikan. Di antaranya metode kisah, metode tanya jawab, metode diskusi, metode teladan, metode pembiasaan dan metode ceramah.

Dalam pembelajaran PAI metode kisah digunakan untuk memperkuat pemahaman peserta didik dengan mempelajari kisah-kisah pada masa nabi dan sahabat. Metode kisah paing tepat digunakan pada materi sejarah Islam. Metode tanya jawab dan diskusi digunakan untuk memperkuat ingatan dan pemahaman peserta didik terhadap suatu materi.

Metode teladan digunakan untuk materi yang dipraktikkan. Untuk materi yang ada praktik lebih baik menggunakan metode teladan, tidak hanya materi. Contohnya pada materi ibadah yaitu salat, guru harus memberikan contoh tata cara salat. Peserta tidak akan paham jika guru hanya memberikan teori tata caranya. Metode pembiasaan dilakukan untuk menguatkan hafalan Alquran peserta didik. Terakhir metode ceramah 
pada pembelajaran PAI dugunakan untuk penyampaian materi yang hanya bersifat teori tetapi juga harus ditambah dengan metode tanya jawab atau diskusi agar peserta didik lebih paham.

4) Implikasi terhadap evaluasi
pembelajaran
Implikasi evaluasi pendidikan Islam menurut Mahmud Yunus terhadap pembelajaran PAI dapat dilihat dari macam-macam evaluasi yang dilakukan. Evaluasi yang dilakukan berupa ulangan harian, ujan semester, ujian nasional. Evaluasi ini dilakukan untuk mengetahui tercapai atau tidaknya tujuan dilaksanakannya pembelajaraPAI

Ulangan harian dilakukan untuk mengetahui ketercapaian pemahaman peserta didik terhadap setiap bab materi yang telah dipelajari. Misalnya peserta didik sudah selesai mempelajari bab akhlak, kemudian diakhir bab peserta didik diberikan evaluasi mengenai akhlak. Setelah evaluasi dilakukan, diketahui hasil evaluasi peserta didik, jika tidak mencapai tujuan yang diinginkan maka akan dilakukan tidak lanjut. Maka tindakan selanjutnya adalah guru memperbaiki metode pembelajaran dan peserta didik memperbaiki cara belajarnya agar tujuan pembelajaran PAI tercapai.

\section{KESIMPULAN}

Berdasarkan hasil penelitian ini dapat disimpulkan bahwa konsep pendidikan Islam perspektif Mahmud Yunus dan implikasinya terhadap pembelajaran PAI di sekolah, sebagai berikut:

1. Dalam menyusun rencana pegajaran pendidikan Islam, ada asas-asas yang harus diperhatikan, yaitu menen- tukan tujuan pendidikan Islam. Selanjutnya dalam membuat materi pendidikan Islam atau mata pelajaran harus disesuaikan dengan kondisi peserta didik. Materi yang diberikan haruslah memunculkan keaktifan peserta didik dan memberikan manfaat kepada peserta didik di masa kini dan masa yang akan datang.

2. Tujuan pendidikan Islam menurut Mahmud yang utama adalah agar dengan pendidikan Islam peserta didik memiliki akhlak yang mulia. Pendidikan Islam akan dianggap berhasil jika peserta didik memiliki akhlak mulia. Selanjutnya tujuan pendidikan Islam Mahmud Yunus adalah agar peserta didik dapat cakap atau dihandalkan dalam bidang ilmu pengetahuan duniawi dan akhirat. Peserta didik diharapkan dapat memahami ilmu dunia misalnya ilmu-ilmu umum (matematika, IPA, IPS dan lai-lain) dan ilmu akhirat yaitu ilmu yang mempelajari tentang Islam (akhlak, keimanan, dan lain-lain).

3. Untuk mencapai tujuan pendidikan Islam tersebut maka dibutuhkan pendidikan Islam dengan penyampaian materi yang tepat kepada peserta didik. Mahmud Yunus membagi materi pendidikan Islam secara umum menjadi tiga yaitu untuk mendapatkan ilmu pengetahuan (matematika, fisika, sastra, dan sebagainya), untuk mencapai ketangkasan dan kemahiran (menggambar, menulis, keterampilan dan sebagainya) dan untuk memperhalus perasaan peserta didik (seni musik, melukis dan lain-lain). 
Selanjutnya secara khusus Mahmud Yunus membagi materi Pendidikan Islam berdasarkan tingkat pendidikan.

4. Materi pendidkan Islam akan mudah dipahami oleh peserta didik jika guru menggunakan metode atau cara pengajaran yang tepat dan setiap materi memilii metode yang berbeda. Mahmud Yunus membagi metode pendidikan Islam berdasarkan materi pendidikan Islam. Secara keseluruhan metode pendidikan Islam menurut Mahmud Yunus yaitu metode kisah, metode tanya jawab, metode diskusi, metode teladan, metode pembiasaan dan metode ceramah.

5. Jenis evaluasi pendidikan Islam perspektif Mahmud Yunus ada empat, yaitu: 1. Ujian sekolah, 2. Ujian umum, 3. Ujian biasa, 4. Ujian modern.

Konsep pendidikan Islam Mahmud Yunus tersebut dapat menjadi rujukan dalam pembelajaran PAI di sekolah, misalnya terhadap tujuan pembelajaran PAI yang hasil akhirnya bahwa pendidikan Islam harus menghasilkan peserta didik yang tidak hanya handal dalam ilmu umum atau hal-hal yang duniawi tetapi juga handal dalam ilmu dan amalan yang akan dibawa hingga akhirat nanti. Dan untuk mencapai hal tersebut maka peserta didik harus mencapai tujuan utama pendidikan Islam yaitu berakhlak mulia; materi pembelajaran PAI yang terdiri dari keimanan, akhlak, ibadah, Alquran dan hadis, sejarah Islam, Islam dan kemasyarakatan; metode yang dapat digunakan adalah metode kisah, meotde tanya jawab, metode diskusi, metode teladan, metode pembiasaan dan metode ceramah; dan evaluasi pendidikan Islam yang terdiri dari macam-macam evaluasi. Evaluasi yang dilakukan berupa ulangan harian, ujan semester, ujian nasional.

\section{REFERENSI}

Asnawan. (2011, Maret). Kontribusi Pemikiran Mahmud Yunus dalam Pembaharuan Pendidikan Islam di Indonesia. Falasifa, 2, 17-33.

Budi, Rahmat, M., \& Kosasih, A. (2015). Efektivitas CD Interaktif dalam Pembelajaran Pendidikan Agama Islam untuk Meningkatkan Hasil Belajar Siswa SMP. Pendidikan Agama Islam-Ta'lim, 13, 191-200.

Fahrudin. (2014). Proses Pendidikan Nilai Moral di Lingkungan Keluarga Sebagai Upaya Mengatasi Kenakalan Remaja. Pendidikan Agama Islam-Ta'lim, 12, 41-54.

Fakhruddin, A. (2014). Urgensi Pendidikan Nilai Untuk Memecahkan Problematika Nilai dalam Konteks Pendidikan Persekolahan. Jurnal Pendidikan Agama Islam -Ta'lim, 12(1), 79.

Gunawan, I. (2014). Metode Penelitian Kualitatif Teori dan Praktik. Jakarta: Bumi Aksara.

Herry Muhammad, d. (2006). Tokohtokob Islam yang Berpengaruh Abad 20. Jakarta: Gema Insani.

Nata, A. (2005). Tokoh-tokoh Pembaharuan Pendidikan Islam di Indonesia.Jakarta: Raja Grafindo Persada. 
Ramayulis. (2008). Ilmu Pendidikan Islam. Jakarta: Kalam Mulia.

Sugiyono. (2016). Metode Penelitian Pendidikan (Pendekatan Kuantitatif, Kualitatif, dan R\&D). Bandung: Alfabeta.

Sutikno. (2013). Pola Pendidikan Islam dalam Surat Luqman 12-19. Pola Pendidikan Islam, 02, 288-302.

Tafsir, A. (2011). Ilmu Pendidilkan Dalam Perspektif Islam. (T. Surjaman, Ed.) Bandung: PT Remaja Rosdakarya.

Yunus, M. (1983). Metodik Khusus Pendidikan Agama. Jakarta: PT Hidakarya Agung Jakarta.

Yunus, M. (1990). Pokok-Pokok Pendidikan dan Pengajaran. Jakarta: PT Hidakarya Agung Jakarta.

Zed, M. (2008). Metode Penelitian Kepustakaan. Jakarta: Yayasan Obor Indonesia.

Zulmardi. (2009, Juni). Mahmud Yunus dan Pemikirannya dalam Pendidikan. Ta'dib, 12, 11-21. 